\title{
VEEKOGUDE JA TEEKONNAGA SEOTUD KOHANIMESID EESTI LÕUNAPIIRIL
}

\author{
MARIKO FASTER
}

\begin{abstract}
Annotatsioon. Artiklis arutletakse mõningate etümoloogiate üle, mis puudutavad Lõuna-Eesti kohanimesid, nendega seostuvaid kohanimesid mujalt Eestist ning läänemeresoome keelealalt. Vaatluse all on nimed, millele pilku heites jääb nende tähendus esmalt hämaraks. Lähemalt selgitatakse asjaolusid, miks Valga nimele sobib ikkagi kõige paremini tähenduseks slaavi päritolu apellatiiv volok 'paatide ülevedamise koht', mitte mõni muu balti või läänemeresoome sõna. Taheva nimi lähtub läänemeresoome sõnast taive tähenduses 'käänukoht, käänak'. Sellesse nimepessa kuuluvad veel mitmed Eesti asulanimed, nt Taebla ja Tahula. Esimest korda esitatakse Saru ja Hargla etümoloogiad. Mõlemad nimed on tõenäoliselt lähtunud apellatiivist, mis tähistab peajõe haru, kuid on vanuse poolest erinevad. Artiklis ilmneb, et kohanimede etümologiseerimisel on peale nimede häälikuliste kujude võrdlemise tähtis tunda ka koha geograafilist iseloomu ning tajuda omaaegse nimeandja motiivi.
\end{abstract}

Võtmesõnad: onomastika, etümoloogia, vetenimed, asulanimed, nimeandmispõhimõtted

Artiklis käsitletakse etümoloogiliselt mõningaid Lõuna-Eesti kohanimesid, mis on lähtunud omal ajal harilikest sõnadest. Käsitletavatel nimedel on kirjalikele allikatele tuginedes vanust keskmiselt viissada aastat (tegelikult ilmselt rohkemgi), nii et neis sisalduvad harilikud apellatiivid ja võimalikud teised tavakeele sõnad on keelekasutaja meeles tänapäevaks muutunud hämaraks, tundmatuks või arusaamatuks.

Artiklis tuleb juttu mõnest Eesti lõunapiiri äärsest veekogude ja teekonnaga seotud kohanimest, mille aluseks on olnud paiga geograafiline iseloom ja muidugi suhe inimesega. Uurimus on etümoloogiline, ent rõhutatakse ka kohanimeuurimuses oluliseks peetavat nimede motiveeritust. Artiklis käsitletakse järgmiste nimede etümoloogiaid: Valga (linn), 
Taheva, Saru, Hargla (külad) ja Mustjõgi, Peetri jõgi, Hargla oja (veekogude nimed), ning samuti võimalikke apellatiive, mis on nende nimede aluseks.

\section{Valga}

Valga (läti Valka) nimi on Lõuna-Eesti kontekstis erandlik selle poolest, et selle üle on nii palju arutletud. Vaid mõni kohanimi on uurijatele sedavõrd palju huvi pakkunud.

Nimi ise esineb allikates esimest korda 1286. aastal (BHO: Walk, Valgamaa: 132; Mägi, Veri 1976: 13). See on üles kirjutatud ühte Riia linna võlaraamatusse, kuhu on märgitud kaks võlgnikku Johannes clericus de Walko ja Johannes Stedinc de Walko, mõni aasta hiljem veel kolmas, Thidericus de Walco (ka Walke). Arvatakse, et nad olid kaupmehed ja et nime lõpuosis näitab nende pärinemist Valgast. Hiljemalt XIII sajandi teiseks pooleks oli Valga ,alev, kus ei puudunud kaupmehed, kelledel oli suuremaid äritehinguid ja laialdasemaid sidemeid" (Valgamaa: 546). Valga on olnud tähtis koht, see on asulana küllaltki vana ning seda on varajastes lätetes korduvalt nimetatud oppidum'iks (ladina keeles 'linn'). Valgal on olnud isegi oma pitsat ja vapp. Ametlikud linnaõigused sai Valga alles keskajal, 1584. (BHO: Walk; Mägi, Veri 1976: 13) Keskaegsel Valgal on puudunud paadist suuremate laevade jaoks kõlblik veetee, aga arengu põhjuseks peetakse asendit suure Tartu-Riia sõja- ja kaubatee ääres ning pääsu Pihkvasse Kirumpää ja Vastseliina kaudu (Valgamaa: 546). Valga asukoht keset vana Liivimaad soodustas seal koosolekute pidamist (BHO: Walk; Valgamaa: 132). Kohanime üleskirjutused on järgmised: 1345 Walken, 1387 Walk, teised kujud Walke, Walck, Walcke, Walken, Walckede, Valk (BHO: Walk; Valgamaa: 546).

Valga nime kõrval on kogu aeg esinenud ka teine nimi. See on tänapäevasel kujul Pedeli - oja, mis voolab läbi Valga. Küla on kutsutud oja järgi ja asustusüksuse nimena on see kõrvale jäänud: *Põdeli > 1369 Podel, 1383 Podelis od. up den Valk (BHO: Walk). Alamsaksakeelne üleskirjutus ütleb, et „Podelis ehk Valk'i peal (kohal)”, vrd võru Leegust kottal 'Leeguste talu juures, lähedal (nt tee peal)'. Valk ei tundu selles üleskirjutuses olevat mitte asustusnimi, vaid lihtsalt suhteliselt tavaline maastikukoha nimi. Pedeli nimi võiks omakorda kuuluda nimepessa, kuhu kuuluvad teised Ped-algulised hüdronüümid, nagu Pedja ja Pedetsi. 
Kohanime algupära on uurijatele huvi pakkunud juba pikka aega. Esimesena kirjutas nimest Max Vasmer (1923: 75), kes arvas, et nimes sisaldub vene laen волок 'paadi ülevedamise koht; jõgedevaheline koht, kust saab paate üle vedada'. Seda sõna peetakse vene keeles slaavi omasõnaks, vrd verb волочить 'lohistama, tirima, tassima'. Hiljem hakati mõtlema, mis jõest mis jõkke paate veeti, ja üldiselt on arvatud, et need jõed olid Pedeli ja Koiva (Mägi, Veri 1976: 13; Saks 1984). Mõnes mõttes võib selle arvamuse põhjuseks olla ka teade, et tsaariajal, 1822. a, plaaniti kanalit Pedelist otse Koivasse (Valgamaa: 481; Saks 1984). Samas on see tee ka väga ahvatlev, sest Koivat mööda saab otse Riia linnani välja. Ojars Bušs on teekonna Pedelist Koivasse uuesti vaatluse alla võtnud ja väitnud, et ajaloolased pole leidnud tõendeid selle kohta, et nende jõgede vahel oleks paate veetud (Sepper jt 2004: 555). Jõgedevaheline ala on umbes $10 \mathrm{~km}$ pikkune ja see ongi ehk Liivimaa väikestes jõgikondades liiga pikk maa paatide vedamiseks. Samas on Valga looduslik asend ikkagi väga soodus pääsemaks ühest jõgikonnast teise. Võib-olla lohistati paate Pedelist mööda Konnaoja orgu Säde jõele (lt Seda) (umbes poolteist kilomeetrit)? Ehkki ka selle kohta puudub tõendusmaterjal, oleks see üleveoteekond lühike ja sobiks just tänapäevase Valga südalinna kohale. Niiviisi saaks väljapääsu Säde jõe, Burtnieki järve ja Salatsi jõe kaudu Salatsi liivlaste aladele ning merele; teiselt poolt pääseks Väiksele Emajõele ja Võrtsjärvele, sealt Emajõe kaudu Tartusse ja edasi Pihkvasse. Säde jõgi, salatsiliivi aladel tuntud ka kui Ymera, „oli peamiseks idapoolseks veeteeks Salatsi aladele” (Pajusalu, Winkler 2011: 180).

Valga nime lähtumist paatide üleveo kohta tähistavast sõnast волок tuleb pidada kõige tõenäolisemaks, sest linna geograafiline asend annab selleks hea põhjuse. Selline seletus pole aga mitmeid uurijad rahuldanud. Seepärast on pakutud linna nime lähtumist mitmest valk-algulisest sõnast: valk 'löömariistad, pistrik'; valkama 'rängasti sadama, valgeks lööma, maadlema, võitlema'; valkistama 'valgeks, valkjaks või heledaks tegema, pleegitama'; walko 'välk, valguskiir, valgus'; valketa 'valge' jt (Kettunen 1955: 264; Saks 1984). Nendes seletustes jääb aga nõrgaks pooleks nimeandmismotiiv. Ojars Bušs pakub, et nimi võiks olla seletatav ka balti keeleainese põhjal, ja oletab nime pärinemist apellatiivist valks 'oja'. Bušsi sõnul on aga valks-komponendiga nimed laialt levinud ainult Kuramaal, mis jääb Eesti piirist kaugele (Bušs 2003: 35). Läti sõna valgums 'paadisadam, kalastuspaik' on peetud laenuks läänemeresoome keeltest (Häkkinen 
2005: valkama). Tegu ei ole ei balti ega läänemeresoome päritolu nimega, vaid hoopiski nimega, mille aluseks on slaavi päritolu sõna. Tõenäoliselt ei näitagi Valga nimi slaavlaste kohalolu seal kandis, vaid hoopis seda, et kohalikud läänemeresoomlased on laenanud transpordi oskussõna ja see on kohanimeks saanud.

Õigustatult kerkib küsimus vene sõna волок ja läänemeresoome valgma $<*$ valkama vahekorrast. Valkama on soome keeles saanud endale just lohistamistähenduse: paadi kaldaletõmbamise koht, saviaugust koorma välja tõmbamise koht jne. Sama ilmneb ka eesti keeles: valgma on eelkõige paatide väljatõmbamise koht ja väike paadisadam. Peipsi ärre vene keeles on наволок tuntud nii tänapäeva vene keeles kõige üldisemaks saanud tähenduses намытыій мыс 'uhutud neem' kui ka paatide väljatõmbamise koha tähenduses.

Mõned uurijad, näiteks Jorma Koivulehto, on arvanud, et valkama on slaavi laen sõnast волокъ (Janne Saarikivi suuline teade). Olli Nuutinen (1989: 42-43) pooldab samuti laenulisust. A. I. Popov on kirjutanud, et muudes slaavi keeltes olemas olnud tähendustele on vene keeles lisandunud kahe jõe vahelise üleveokoha tähendus, mis võiks olla läänemeresoome keelte mõju (Popov 1972: 86-87).

Üldiselt on arvatud, et valgma on tuletis tüvest valguma, nagu sadam on tuletis verbist sadama (SSA: valkama; EES: valgma, sadam). $m A$-lõpulised nimisõnatuletised verbist pole tänapäeva eesti keeles tavalised (vrd siiski nt sö̈m ja joom), ent vanas kirjakeeles ja murretes on neid kuigivõrd tuntud (Ross 2009: 900), samuti teistes läänemeresoome keeltes (Laanest 1975: 137-138). Soome keeles on $m A$-element nimisõnades samuti olemas, näiteks esineb varieerumist sõnades reuna $\sim$ reunama, ehk siis ka valka valkama. $m A$-elementi võiks seletada teisalt ka lühenemisega - sel juhul oleks tegemist sõnade valg-maa kontamineerumisega (Janne Saarikivi suuliselt), millele pakub tuge ka liivi keele vorm vālga-mō' valgma, kalasadam' (Viitso, Ernštreits 2012: vālgamō), ehkki liivi keeles võib tegu olla ka rahvaetümoloogilise reanalüüsiga.

Soomes on olemas nii Valkama, Valkamaa kui ka Valkamamaa kohanimed. Tavaliselt on tegemist kohtadega veekogude rannas, kuid mõnikord näitab kaart ka kunagise üleveokoha olemasolu kahe veekogu vahel või järves üle maakitsuse ühest lahest teise. Mitmed tänapäeval Valkea-algulised nimed Soomes on arvatavasti varem olnud valgma-nimed, millele viitab kohtade geograafiline asend. 
Ka valgma järgi on Eestis mitmeid kohti nimetatud, nt Valgma küla Harjumaal (Ris), Jõgeva maakonnas (Äks) ja Paide maakonnas (Pai). Kärkna mõisa saksakeelne nimi on Falkenau, vanades allikates 1305 Valkana, 1341 Valkena, 1408 Falckenaw, 1417 Valkena, 1532 Valkanha, 1782 Falkenau, 1900 Falkenau (Uustalu 1972: 23). Valgma asub kohas, kus Amme jõgi suubub Emajõkke, ka klooster asus just Emajõe ääres. Valdek Pall ongi arvanud, et selle nime aluseks on olnud valgma (Pall 1969: 265). Saadjärve küla on XVII saj kuulunud Walckama mõisale (Uustalu 1972: 118; BHO: Sadjerw). Võnnu kihelkonnas asub Tammevalgma küla ja mets nimega Valgma, millest saab alguse väike Luutsna jõgi.

Ka vana tuntud Walgatabalwe sisaldab eelmistele lähedast sõna. Walgatabalwe asustusüksus polnud algupäraselt suurem kui vana keskusküla või vakus Vastseliina keskosas (kohanimena säilinud kuni XVII sajandini), kuid keskajal on seda nime mainitud isegi Kirumpää-Kasaritsa piiril, nii et nime suurim mõjuala võis olla Rõuge-Vastseliina kaksikkihelkond, seda niikaua, kui Vastseliina nimi vana nime välja tõrjus (suuliselt Evar Saar). Walgatabalwe on ka arheoloogide arvates asetsenud Vastseliina kandis ja kusagil teede ristumise kohas (Laul 1999: 59), mitte aga Valga lähedal, nagu varem samuti arvatud (Ernits 1978: 159). Kohta võiks seostada ka paatide ülevedamisega, näiteks saab Vastseliina kandis minna Peipsi vesikonnast Väina ehk Daugava jõe vesikonda. Peipsilt Daugavasse pääsemiseks tuli paadid lohistada Piusa haruojadelt vähemalt Kirikumäe järveni. Vähim vahemaa on olnud paar kilomeetrit.

Kohanime teine pool -balwe sisaldab tõenäoliselt mingit kadunud terminit, mis on tähistanud asustusüksust (*palva *palwe, vrd handi puyal jt, mansi pawal jt, ungari falu 'küla; asustusüksus') ja mis võiks vanadele üleskirjutustele tuginedes sisalduda ka mõningates Eesti nimedes, mis sisaldavad palu-komponenti (Saarikivi 2006, teine $\operatorname{artikkel}^{1}$ : 32) või ka pala-komponenti.

Sufiks -ta nimes Walgatabalwe ja ka ühes teises Lõuna-Eesti nimes Valguta (1582 Walkuth, 1626 Walgets Külla, Walgats Külla, 1638 Walgata, 1711 Walkota, 1726 Welgota (Uustalu 1972: 151; BHO: Walguta) Võrtsjärve ääres Rõngu jõe alamjooksul juhib oletama, et paadilohistamisega seotud slaavi laensõnast on edasi tekkinud ka verb *valkata. Selle hüpoteetilise verbi ma-partitsiip (agentpartitsiip) oleks *valkama ja

${ }^{1}$ On the Uralic substrate toponymy of Arkhangelsk region: problems of research methodology and ethnohistorical interpretation. 
semantilise läheduse tõttu oleks lihtne kujutleda verbi käändelise vormi ümbertõlgendamist uueks nimisõnaks. Tuletuskäik võiks siis olla selline:

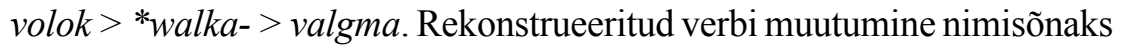
valkama $\sim$ valgma võib vajada põhjalikumat seletust, kuid põhimõtteliselt võimatu selline areng pole. Tuge pakub ka Peipsi lõunaosas leiduv madaliku nimi Vedämä leede, kus põhimõtteliselt samas vormis on kasutatud verbi vedada: vedama. Pigem sunnibki hüpoteesis kahtlema tõsiasi, et valgmaga seotud verbi ennast pole läänemeresoome keeltes säilinud.

\section{Taheva}

Taheva nimi ilmub ajalooallikatesse XVI sajandil koha- ja külanimena: 1541 (Wacke) Tayewes, 1551 Tayuen, Tayues, 1582 Thaiwenkul, 1627 Taywa, 1688 Taiwola, Taiwula, 1711 Taiwala; mõisanimena 1782 Taiwola, 1826 Taiwola, 1909 Taiwola ehk Taheva mõis; dateerimata üleskirjutus Taywaküll (Rev 1624/27: 97; Uustalu 1972: 131-132). Rahvasuus ongi levinud variant Taivakülä (vrd taivas : taiva 'taevas'), mida on tõepoolest nendest variantidest lihtne tuletada.

Nime esimene üleskirjutus lõpuga -wes viitaks justkui vesi-lõpulisele nimele. Tõepoolest on Taheva tuntud ka jõenimena (Mustjõe varasem nimi, vt allpool). Vesi esineb liigisõnana mitmetes Lõuna-Soome järvede ja järveosade nimedes, nt Välivesi, Majavesi jt, ent mitte jõenimedes (SPNK: vesi). Valdek Pall on arvanud, et Peipsi paralleelnimetus võis minevikus olla ka *Mustvesi ja tõenäoliselt on Mustvee linn saanud oma nime just järvelt, aga võimalik, et ka jõelt (<Mustwet) (EKNR: Mustvee; Pall 1969: Mustvee linn). Oleks aga vaja rohkem näiteid tõestamaks, et Eesti alal võis vesi esineda ka jõenimedes. Taheva varasemad mainimised Tayewes $\sim$ Tayues ja genitiivikuju Thaiwen- ei näita tõenäoliselt mitte liitnime sõnaga -vesi, vaid mingit tuletist, mis on struktuurilt (ja ehk isegi kõigi vokaalide poolest) identne homonüümiga taivas.

On arvatud, et nime aluseks on apellatiiv taival $\sim$ taipale (Tarvel 1975), millel on soome keeles tähendus 'kahe koha vaheline vahemaa, tee, kaugus' või 'teekond, rännak, matk, reis', ka 'kõrgem koht vete vahel'; varasem tähendus on ehk olnud ka 'maastikus olev käänamis- või hargnemiskoht' (SSA: taipale). Viimane tähendus sobib Taheva nime puhul hästi, sest just Taheva juures suubub Mustjõgi Koiva jõkke. See veetee Riiga on käigus olnud juba ammu ja veel XX sajandilgi. Taheval on olnud ka jõeületuskoht 
teel Koivaliina. Taheva häälikuline seostamine sõnaga taival taipale pole siiski probleemitu.

Takistavaks asjaoluks on sõnas taival leiduv -1 , mis võib nime saksakeelses kujus Taiwola olla säilinud, kuid see võib kuuluda ka vanades külanimedes tüüpiliselt kasutatud $l a$-liite juurde, mis nime tänapäevakujust ja mitmest varasest mainimisest tervikuna puudub. Väiksem on probleem teise silbi $h$-ga, mida võib suure tõenäosusega pidada hiaatuse teel tekkinuks. Vrd lõunaeesti seen 'sees' ja käen 'käes' kujusid Mulgi murdes: sehen ja kähen. Nime häälduse mulgipärast arengut Mulgimaast mitte kaugele jäävas Tahevas ei saa igatahes välistada.

Tüvest *taipe- <*taj(e)- (sm taipua 'painduda, kõverduda', taivuttaa 'painutada, käänata') on tulnud nii apellatiiv taipale $\sim$ taival kui ka apellatiiv taive 'käänukoht, käänak' (SSA: taipua). Taheva puhul tuleks lähtuda apellatiivist taive 'käänukoht, käänak'. Sõna on ilmselt kuulunud muistse teekonnasõnavara hulka, mille tõttu on uurijatele alates Lönnrotist tundunud, et näiteks Soome saarenime Taivassalo algupära võiks olla *Taivalsalo. Kirjapandud nimekujud $l$-i esinemist selles nimes ei kinnita, nt esmamainimine 1350. a Thowesalu (SPNK: Taivassalo).

Eestis on kaks kohanime, mille puhul apellatiiv taival taipale tähenduses 'vahemaa, tee, teekond, matk, reis' või 'käänamis- või hargnemiskoht' sobib seletuseks laitmatult. Üks neist on Taebla. Nime varasemad üleskirjutused on 1341 Taybile, 1530 (?) Taybell, 1798 Taibel (EKNR: Taebla). Taebla puhul oleks nimeandmismotiiviks 'kuivamaateede algus Harjumaa poole', teisisõnu 'teekonna algus'. Seda seletust on pakkunud nii Saareste (2006: 103) kui ka Kettunen (1955: 90). Ehkki Kettunen on pakkunud nime aluseks ka muid sõnu, tuleb apellatiivist taival lähtumist pidada kõige tõenäolisemaks.

Teine vana nimi, mis on säilinud saksa keeles, kuid suulises pruugis eesti keelest kadunud (nähtus on küllaltki tavaline, vrd nt Eisen 1924), on Sangaste kihelkonna nimi Theal. See pole kunagi olnud küla, vaid lihtsalt kiriku ümbruse ja kiriku nimi. Nime üleskirjutused on järgmised: 1379 Touvel, 1499 Thoyvell, 1582 Thewal, 1627 Teubel Theol, 1638 Teal Theal (EKNR: Sangaste). Nimekujudest paistab läbi lähtumine apellatiivist taival taipale. Geograafiliselt sobib see seletus samuti hästi: kirik on ehitatud kohta, kus lõppes Väikese Emajõe veetee ja läks üle maismaateeks (või vastupidi). Sangaste külal ja mõisal, mis asuvad kirikust kaugemal, on olnud teine nimi - Sangaste (sks Sagnitz) - mis on andnud kihelkonnale 
eestikeelse nime. Hiljem on kiriku ümbruse algupärane nimi kadunud ja siingi on tänapäeval tuntud vaid Sangaste nimi.

Suure-Jaani kihelkonna külanimi Taevere võib olla lähtunud apellatiivist taive 'käänukoht, käänak' või ka 'teekonna algus'. Koht asub Lõhavere linnamäest Navesti jõe poole. Lõhavere on Suure-Jaani kihelkonna vana keskus. Taevere on koht, mille kaudu pääses mööda Lõhavere oja Navesti (Paala) jõele. See oli tuntud veetee, mida mööda sai Pärnu jõele ja edasi Pärnu lahte. Mõisanime üleskirjutused on järgmised: XVI saj Taifer, 1599/1601 Teyfer, 1638 Taifer, 1681/83 Teiferhoff, 1729 Tayfehr, 1782 Taifer Taefer, 1871 Taifer, 1909 Taifer ehk Taewere (Uustalu 1972: 131). Nagu näeme, võiks sõna taive lõpuosa olla kokku langenud vere-formandiga, kuid Taevere nime võib vabalt tõlgendada ka teistsuguse algupära kasuks.

Kui võtta aluseks üksnes nime kõige vanemad mainimised, võiks sellesse nimepessa kuuluda ka Tahula (küla Saaremaal Kaarmal). Tahula nime on üles kirjutatud järgmiselt: 1453 Teuwel, 1525 Thauwell, 1546 Tachull (vakus), 1592 Tahewall, 1645 Tahul (EKNR: Tahula). Tahula nime puhul tuleb silmas pidada seda, et sadu aastaid tagasi oli rannajoon teistsugune ning sel juhul võiks tegu olla näiteks merelaheäärse kohaga või ka kohaga, kust pääses maismaad mööda ühest sügavale maasse ulatuvast merelahest teise. Tahula kirjalikest mainimistest võib soovi korral välja lugeda kas $h$ lisandumise nimesse diftongi au kahte silpi jagunemise piiril (hiaatus) või siis selle, et $h$ jäeti kõige varasemates kirjapanekutes märkimata ja nimi ei ole taival-algupäraga.

Viimasena võiks oletuslikku nimepessa kaasata Tõivere (küla Põltsamaa kihelkonnas), mille nimi on üles kirjutatud nii: 1583 Teiwer (küla), 1599 Taywer, 1624 Teyfer, 1797 Toifer (EKNR: Tõivere). Siin pälvib tähelepanu lihtsalt nime ja selle varasemate mainimiste sarnasus Taevere nimekujudega. Küla paikneb oma kandis Põltsamaa jõele kõige ligemal, nimesaamise motiiviks sobiks hästi 'teekonna algus' või ka 'käänak', ent nime tänapäevane kuju lubab oletada ka muud algupära. 


\section{Mustjõgi ja Peetri jõgi}

Mustjõgi on üks Koiva suuremaid ja tähtsamaid lisajõgesid, mis voolab nii Võru kui ka Valga maakonnas. Mustjõe nimi (sks Schwarzbach) ilmub allikatesse esimest korda 1627. aastal. Keelejuhid on nime saamist põhjendanud vee värvusega, sest sinna voolab ülemjooksul soisest pinnasest pärit tumedat vett. Nimi võib siiski olla ka vanem, sest Vana-Roosa kandis on 1561. aastal mainitud asustusnime Мустовери, millest hiljem teateid pole. (EKNR: Mustjõgi) Nime teeb huvitavaks asjaolu, et Mustjõe lisajõgi Peetri jõgi (kohalik kuju ka Piitrejõgi) kannab läti keeles nime Melnupe 'must jõgi', mida eesti keeles ei teata. Vanemad inimesed mäletavad, et Peetri jõgi kandis nime Ihte jõgi. Ihte on olnud küla jõe ääres, mille nime on tuntud veel XIX sajandilgi (praegune Tursa). Jääb mulje, et külanimi on olnud primaarne, millele viitab 1638. aasta üleskirjutus Vchtikulle Jegge (Rev 1624/27: 217). Ihte nime etümoloogia on praegu ebaselge.

Peetri jõe nimi on suhteliselt noor ja ilmselt saanud nime arvukate Peetrite järgi, kes elasid jõe ääres XVIII saj lõpupoole. Nimed Mustjõgi ja Melnupe võivad nii Eesti kui ka Läti traditsioonis tähistada alamjooksul ühte jõge, kuid ülemjooksul erinevaid harusid.

Mustjõe varasemad nimekujud varieeruvad: 1627 Schwartzbeche, Fursche Beche, Thaywa, Scharra, 1638 Schwartze beche, Fyrische beche, 1798 Schwarzbach (EKNR: Mustjõgi). Näeme, et jõge on nimetatud kooskõlas asulatega kord Tsooru (Fierenhof), Taheva (Thaywa) või Saru (Scharra) järgi. Taheva kui jõenimi on olnud kõige laiemalt tuntud. Seda tunneb isegi Vene kroonika aastast 1564: „от Треката городка за Таговесью рекою и хотљли через рљку љхати воевати на Рожину мызу" 'Trikata kantsist Taheva jõe tagant ja tahtsid tulla üle jõe sõjakäiguga Roosa mõisasse' (Ambus 1960: 743). 1624. ja 1627. aasta revisjonis kirjutatakse Mustjõe ühe suurema haru Pärlijõe kohta aga järgmist: „Ein Strom fleust in die Scharra undt hernach in die Aa” 'üks jõgi [Pärlijõgi] voolab Scharrasse [Mustjõkke] ja seejärel Koivasse'. Sellest võib järeldada, et Scharra on jõenimi, mis võis tuntud olla ka alamjooksul. Samas revisjonis mõni lehekülg edasi loeme, et Mõniste ja Saru maadel voolab kaks suuremat jõge: Waydwa ja Thaywa, viimase all mõeldakse samuti Mustjõge. Saru nimi võiks pärineda just sellest erandlikust jõenime mainimisest Scharra, mis arvatavasti ongi Mustjõe kõige vanem kirjalikus vormis säilinud nimi. 


\section{Saru}

Saru küla ja vakust on esimest korda mainitud 1386: die Wacke zu Sarrega mit dem Dorf Sarrego, siis 1419 die Wacke Sargo mit dem Dorf, 1443 die Wacke zu Tzergo, 1449 Tzargo. Mõisanime on üles kirjutatud niimoodi: 1529 Sarck, 1542 Sarge, XVI saj lõpul - XVII saj algul Sara Moysa, Sarwehoff, 1627 Saaramoyse, 1638 Sarwehoff, Sarwe, 1782 Sahren e Saru, 1826 Sara, 1909 Saara (LGU: 119, 208, 312, 338; Uustalu 1972: 116; BHO: Saara). Nime suhteliselt erinevad üleskirjutused on silma jäänud Paul Johansenile (1952), kelle arvates hilisemad variandid on mõjustatud tuntud juudi naisenimest Saara, mis on tõenäoline küll, kuid see on mõjutanud ilmselt ainult kirjapilti, mitte nime tegelikku hääldust. Sarvõkülä on arvatavasti rahvaetümoloogia (vrd sarv > saru, järv > järu), mille järgi on pandud Saru külas ka perekonnanimeks Sarv. Selline häälikuline muutus on Eesti murretes küll tuntud, kuid kohanimes jääb selgusetuks nimeandmismotiiv. Eestis ei ole sarv : sarve harilik külanime andnud apellatiiv. Leidub kõigest kolm Sarv-algulist küla, millest üks (Sarve Hiiumaal) on võrdlusnimi (EKNR) ja üks isikunimelist päritolu (Sarvemäe Räpina kihelkonnas) (Evar Saar suuliselt). Ainult Audru kihelkonna Sarvi küla puhul on Marja Kallasmaa arvanud pärinemist apellatiivist sarv : sarve (EKNR).

Lätis on olemas mõned nimed, mis sisaldavad sõna rags 'sarv'. Jūrmala lähedal Ķemeri rahvuspargis on küla Ragaciems 'sarveküla', mis paikneb kitsa ribana järve ja mere vahel. Seega on tegu võrdlusnimega: küla nagu sarv. Nimes Kolkas rags (eesti keeles tuntud kui Kolka neem või Kolka nina) on rags liigisõna positsioonis, kuid ei viita otseselt teatud tüüpi objektile, vaid kirjeldab hoopiski koha tüüpi: tegemist on sarvekujulise kohaga. Neemi ja ahtaid kohti on eri keelte kohanimedes tihti võrreldud sarvega. Leidub päris palju teisigi inimeste või loomade kehaosade nimetustest lähtuvaid liigisõna positsioonis olevaid sõnu.

Soome $\operatorname{Sarv}(i)$-alguliste esiosadega kohanimed on motiveeritud kas sarvekujulisest neemest, sõnast sarva 'pilliroog, heina ja põõsastega madalik' või siis kalast sorva 'roosärg' (SPNK: Sarvi-).

Saru geograafilist asendit vaadates on ilmne, et nime etümologiseerimisel ei paku võrdlus sarvega tuge. Sarve-sõna võiks sellise asula nimeks olla saanud ka mingil muul viisil, näiteks isikunime kaudu. Sellist võimalust ei saa välistada, kuid toetavaid fakte muistse isikunime kohta 
pole teada ja seda ei toeta ka nime varaseimad mainimised. Saru on Eesti pikim ridaküla, mis paikneb lõunakaldega sirgel orunõlval paralleelselt Mustjõega. Küla juures voolab Mustjõkke kõigepealt väike Uskuna oja, siis suur Vaidva jõgi ja seejärel Peetri jõgi.

Apellatiivi, mis võiks sobida selle kohanime aluseks, leiame Soome murretest, vepsa ja lüüdi keelest ning kohanimedest, lisaks ehk ka Põhja-Venemaa substraatsetest kohanimedest: $\operatorname{sar}(a)<* s a(a) r a$ tähendusega 'oja, jõeharu'. Selle sõna sarnane, kuid mitte sama algupära on soome sõna haara 'haru' ( $<$ *hara $<*$ šara). Keel, millest sara-kohanimed pärinevad, oli arvatavasti erinev praegustest läänemeresoome keeltest, sest sellist elementi sisaldavad kohanimed pole eriti sagedased. (Saarikivi 2006, teine artikkel: 31 ). Algupära erinevaks pidamine tuleneb häälikuseadusest: $\check{s}>h$, aga $s$ on jäänud muutumatuks.

Irma Mullonen on Laadoga ja Äänisjärve vahel asuva Ojati jõe vesikonna hüdronüüme analüüsides leidnud siiski, et peale Eestiski tavaliste sõnade järv, jogi 'jõgi' ja oja on nende järel kohanimede üks sagedasemaid liigisõnu ka sar või sara, mille tähendust tänapäeva vepsa keeles enam ei tunta. Nt jõenimed Kondisara, Kuisara, Lepsara jt. Ojati Iõunapoolses naabruses tänapäeval kõneldavas vepsa keeles tähendab see sõna puu hargnemist, oksaharu puul, kuid on ülimalt tõenäoline, et sõna on varem tähendanud ka vooluvee hargnemise kohta ning jõeharu (Mullonen 1988: 28).

Soome etümoloogiasõnaraamatus on samuti olemas sõna saara paralleelkujuga sahra. Selle tähenduseks soome murretes on harkader (mitmusevormis sahrat) (see on Soomes vähem levinud adratüüp). Saarat on harkadra (ühest puust tehtud) kaheharuline teraosa, puust hangu rautatud harud, isuri ja vadja keeles sama harkadra osad. Karjala keeles on šoara tähendusteks antud 'haru, vahe, sama adraosa', lüüdi keeles suar 'puu- või teeharu, jõe ja harujõe vahe, sõrmevahe', vepsa keeles sar 'oja-, tee- või adraharu' (SSA: sahra). Nagu näha, pakubki SSA vepsa keeles ojaharu tähendust, mis Irma Mullose teada on elavast keelest kadunud. Üldistatult on idapoolsete läänemeresoome keelte tähendusväli selle sõna puhul säilinud laiemana kui Eesti vahetu naabruse keeltes, kus tuntakse üksnes harkadra harude tähendust. SSA ei oska sahra-sõna siduda põhjasaami sõnaga sarre 'kahe sõrme, varba või sõra vahe', sest see võib olla hoopis soome haara (eesti hara ja haru) etümoloogiline vaste (SSA: sahra). 
Võimalik, et sahra saara oma lähedaste läänemeresoome vastetega on idapoolse läänemeresoome tagasilaen keelevormist, kus läänemeresoome häälikuseaduslikku muutust $* \check{s}>h$ ei toimunud. Selle sõna leviku piire näitavadki kõige paremini sar-elemendid idapoolse läänemeresoome ala hüdronüümides. Seda, et sõna on kohanimena levinud ka lõunaeesti keele alal, saab panna ainult väga varajaste ja samas oluliste idakontaktide arvele, mis aga ei räägi vastu üldlevinud tõekspidamistele algupärase lõunaeesti keele kuulumise kohta pigem idapoolse läänemeresoome keelevormi juurde.

Saru nime varasemaid üleskirjutusi vaadates on näha, et nimes on esinenud $g$. Klusiili olemasolu või puudumist võiks pidada seda tüüpi sõnade varieeruvuseks. Näiteks sõnast $t$ sori 'väike piklik soine lohk' on olemas ka variandid tsorg ja tsoro. Ka sõnast haru, mis kohanimedes on mõnikord kujul -hara, nt Soohara, Inghara (Räp), esineb variant arg (EMS arg), vrd ka Hargla käesolevas artiklis allpool.

Samuti leidub mainitud vähe levinud sõnale sahra soome keeles vaste üsna hariliku sõna sarka 'põllu- või metsariba' näol (eesti sarg : sara 'maatükk, põllutükk'). Mõlema sõna etümoloogilised seletused viivad tagasi samale tähenduse 'haru' algupärale (SSA: sahra, sarka). Semantiline areng, kus põldude korduv poolitamine ehk kahte harru ajamine on haru tähenduse asemele tekitanud riba tähenduse, on sarka puhul loomulik. Järvamaa kohanime Sargvere aluseks on Lauri Kettunen (1955: 292) pidanud soome sõna sarka : saran 'põlluriba, põld'. Teine võimalus on, et Sargvere on nime saanud sealt mööda voolava jõe järgi. Jõe varasem nimi ei ole teada, kuid Esna jõgi on hiline nimi.

Saru kohta võiks siit üldistada seda, et kuni XVI sajandini esines klusiiliga nimekuju, kuid klusiilita kuju ei ole üheselt klusiili kadumise tulemus, vaid rööpse sõnakuju eelistamine. Seda tõendab illatiivide võrdlus. Sõnast * urka saadud nimedes hääldatakse kohapeal alati illatiivis Urga, Leppurga, Ida-Võru murrakutes Saluorga, Kiviorga, aga Saru illatiivis klusiil ei avaldu: Sarru.

Saru nime tõenäoliselt algupärane kuju *Sara või *Sarga on olnud hüdronüüm. Nime motiveerituseks tähenduse 'haru' kaudu on kaks võimalust: 1) *Sara või *Sarga on tähistanud kogu Mustjõge kui Koiva jõe lisaharu ja Saru küla näol on tegemist selle jõe äärse kõige varasema põllumajandusliku tuumikkülaga, kust asustus on mujale levinud (küla suurus ja soodne asukoht lubab sellist oletust); 2) *Sara või * Sarga nimega 
on tähistatud Mustjõe lõiku Saru küla all, kuhu suubub kõige rohkem harujõgesid, see on andnud nime Saru külale ja küla järgi omakorda on sekundaarselt nimetatud Mustjõge ühel korral XVII saj Scharra.

Küsimusele, miks Saru nimi on $u$-lõpuline, ei ole võimalik üheselt vastata. Juba esmamainimises leiduvad mõlemad kujud. Seda võib tõlgendada, et vakust on nimetatud otseselt jõenimega Sarrega, küla aga modifitseeritult Sarrego. Teades ürikute keele variatiivsust, näib nii peen vahetegemine siiski ülepingutatuna. Suurem osa Saru nime mainimisi lõpeb $a$-ga. Külanime puhul võiks arendada rekonstruktsiooni deminutiivsest liitest *-oi, millest $>-o>-u$, kuid tõenäolisem tundub, et - $o$ ja hiljem $-u$ kinnistumises on mänginud rolli analoogiad, esmalt samatähenduslik sõna haro $(-u)$, hilisemal sarve-algupärale tõlgendamise perioodil aga tõesti liivi- ja mulgipärane sõnakuju saru.

\section{Hargla ja Hargla oja}

Sellenimelist küla pole eksisteerinud enne kihelkonna asutamist. Kihelkond asutati 1694, see sai saksa keeles nimeks Harjel. 1667 mainitakse Koivalinna kihelkonna abikirikut, millel nimeks Harjula, ja XVIII saj algupoolel antakse Taiwakülla maad kooli jaoks: ,.. land ist zum Harjelschen Schuleland abgegeben worden." Rahvasuust on teada, et algselt on Hargla jõenimi, sest vanemad inimesed on mäletanud keelamist: „Älä minnüq Harglõ viirde!’' 'ära mine Hargla äärde'. Niisiis on jõelt saanud nime terve kihelkond.

Aga mida tähendab jõe nimi? 1586. aastal on kirja pandud, et piiskopi ajal tehti paate ja kui vaja peaks olema, võiks ka praegu hakata paate tegema Sangastes Apja ümbruses (circa pagum Sangnicensem appellatum Happia) ja paadid võiks lasta Hargla oja mööda (per fluminem Sara) Mustjõkke (ad flumen Staiwa), sealt edasi Koivasse (ad Gawiam) (Tarvel 1975). Näeme, et Hargla oja nimi on kirja pandud kui Sara ehk siis Saru kohanime valguses lihtsalt 'oja, jõeharu'. Veelgi enam: ka veneaegsel 1947. aasta topokaardil on oja nimeks lihtsalt Arujõgi. Miks on aga Hargla nime alguses $h$, mitte $s$ ? Seletus võib olla selles, et Hargla on noorem nimi kui Saru. Vanem nimi on kivinenud tähistama asulat ja tähendusest ajendatud häälikumuutus on jäänud toimumata. Noorem nimi on säilinud ojanimena ja seda on tajutava tähenduse 'haru' järgi korrigeeritud. Saru ja *Sarg, haru ja harg on omakorda erinevad tüvevariandid: *Sarg tuleb 
ette Saru külanime varastes kirjapanekutes, sõna harg aga esineb näiteks Mõniste mõisa metsas kahe oja vahelist piirkonda tähistava metsaosa nimes Oijõharg.

Lahtiseks jääb veel küsimus, miks ojanimi Hargla lõpeb elemendiga -la. la-d on uurijad enamasti vaadelnud kui väga kindlat asulanime sufiksit. Kuna aga sellenimelist asulat pole varasemas ajaloos olemas olnud, jääb üle nentida analoogiat: paljud Lõuna-Eesti hüdronüümid lõpevad la-ga, nt suured järved Tamula ja Vagula (rahvakeeles on tuntud ka nominatiivikuju Tammul ja Vakul). Lõõdla järve puhul on teada ka kuju Lõõdva. Võimalik, et Lõuna-Eestis, kus la- lõpulisi külanimesid on vähe ja erinevalt Soomest pole talunime niimoodi markeerimine üldse levinud, on la-d tajutud kui üldist kohanimesufiksit, millesuguseks on võinud üldistuda algupärane teistsugune kuju.

\section{Kokkuvõte}

Eesti kohanimedes on reliktseid, kogu läänemeresoome keeleala taustal selgitatavaid sõnu, mis viitavad veeteedele või kohtadele veeteede ääres. Valga nime aluseks on slaavi sõna volok 'paatide ülevedamise koht', nagu tegelikult juba varem on arvatud. Selle seletuse paikapidavust toetab ka paiga geograafiline asend. Teised välja pakutud seletused nii hästi ei sobi, sest ei leidu head nimeandmismotiivi. Veelgi enam, ka apellatiivi valgma 'paatide väljatõmbamise koht' aluseks võib olla volok. Valgma järgi on Eestis kohti samuti nimetatud, kõige tuntum on Kärkna kloostri saksakeelne nimi Falkenau. Samatähenduslik element on ka ajaloolises Walgatabalwe nimes.

Taheva nime aluseks on apellatiiv taive, mille tähenduseks sobiks Eesti oludes kõige paremini tähendus 'käänukoht jõel'. Samasse nimepessa kuuluvaks on tunnistatud ka Taebla ja Taevere, ehk mõned nimed veel. Ka Sangaste kihelkonna saksakeelses nimes $T(h)$ eal võiks peituda just see sõna.

Mustjõgi ja Peetri jõgi on Koiva lisajõed ehk harud. Mustjõe tänapäevane nimi on läbipaistev, kuid võib sellegipoolest olla küllalt vana. Jõge on nimetatud kooskõlas asulatega kord Tsooru (Fierenhof), Taheva (Thaywa) või Saru (Scharra) järgi. Taheva kui jõenimi on olnud kõige laiemalt tuntud. Peetri jõe nimi pärineb arvatavasti XVIII sajandist. Jõe varasem nimi on Ihte jõgi. 
Saru geograafilist asendit vaadates on ilmne, et nime etümologiseerimisel ei paku võrdlus sarvega tuge. Nimi võis algupäraselt olla hüdronüüm (sellele viitavad üleskirjutused dokumentides) ja pärineda idapoolsetes läänemeresoome keeltes kuigivõrd tuntud sõnast $\operatorname{sar}(a)<*^{*} a(a) r a$ 'oja, jõeharu'.

Hargla on algupäraselt olnud ka hüdronüüm (Hargla oja), mille tähenduseks samuti 'haru', ent siin on tegemist nooremast keelekihistusest pärineva nimega kui Saru. la-element hüdronüümides on Eesti alal küllaltki tavaline erinevalt Soomest, kus sufiks tähistab asustusüksusi.

Artiklis ilmneb, et kohanimede etümologiseerimisel on peale nimede häälikuliste kujude võrdlemise tähtis tunda ka koha geograafilist iseloomu ning tajuda omaaegse nimeandja motiivi.

\section{Kirjandus}

Ambus, Ada 1960. Lõuna-eesti kohanimesid Pihkva kroonikais. - Keel ja Kirjandus 12, 736-743.

BHO $=$ Baltisches historisches Ortslexikon. I, Estland (einschließlich Nordlivland). 1985. Begonnen von Hans Feldmann. Hrs. Heinz von zur Mühlen. (= Quellen und Studien zur baltischen Geschichte 8, I.) Köln-Wien: Böhlau Verlag.

Bušs, Ojārs 2003. Personvārdi, vietvārdi un citi vārdi: izpētes pakāpieni. Rīga. EES = Iris Metsmägi, Meeli Sedrik, Sven-Erik Soosaar. Eesti etümoloogiasõnaraamat. Eesti Keele Sihtasutus.

Eisen, M[atthias] J[ohann] 1924. Eesti keelest kadunud, saksa keeles püsinud eestikeelsed kohanimed. - Eesti Keel 3-4, 67-82.

EKNR = Eesti kohanimeraamat. Käsikiri.

EMS = Eesti murrete sõnaraamat. 1994-2013. Tallinn: Eesti Keele Instituut / Eesti Keele Sihtasutus.

Ernits, Enn 1978. Valgatabalve. - Keel ja Kirjandus 3, 159.

Häkkinen, Kaisa 2005. Nykysuomen etymologinen sanakirja. WSOY.

Johansen, Paul 1952. Volksetymologie und Ortsnamenkunde, erläutert am Beispiel Livlands. - Suomalais-ugrilaisen Seuran Aikakauskirja 56 (4), $1-33$.

Kettunen, Lauri 1955. Etymologische Untersuchung über estnische Ortsnamen. (= Suomalaisen Tiedeakatemian Toimituksia B, 90 (1).) Helsinki: Finnische Literaturgesellschaft.

Laanest, Arvo 1975. Sissejuhatus läänemeresoome keeltesse. Tallinn: ENSV TA Keele ja Kirjanduse Instituut. 
Laul, Silvia 1999. Eesti kagunurk - piiriala Pihkva ja ordu valduste vahel. Õdagumeresoomõ veeremaaq. Läänemeresoome perifeeriad. (= Võro instituudi toimõtiseq 6.) Võro, 55-64.

LGU = Livländische Güterurkunden (aus den Jahren 1207 bis 1500). I, 1908. Hrs. von Hermann von Bruiningk und Nicolaus Busch. Riga: Jonck \& Poliewsky.

Mullonen 1988 = Ирма И. Муллонен. Гидронимия бассейна реки Ояти. Петрозаводск: Карелия.

Mullonen 2002 = Ирма И. Муллонен. Топонимия Присвирьий. Проблемы этноязыкового контактирования. Издательство Петрозаводского университета.

Mägi, Heino, Karl Veri 1976. Siin- ja sealpool maanteed. Valga rajoon. Tallinn: Eesti Raamat.

Nuutinen, Olli 1989. Satakunnan synty ja Kainuun kato. - Virittäjä 93, 11-49.

Pajusalu, Karl, Eberhard Winkler 2011. Salatsi liivi kohanimed keelekontaktide kajastajana. - Keel ja Kirjandus 3, 176-189.

Popov 1972 = А. И. Попов. К вопросу о древнейших лексических связях между прибалтийскими финнами и славянами. - Советское финноугроведение 2, 85-89.

Prants, H[indrik] 1925. Põlva. - Postimehe nädalalisa 12.10, 5 (276).

Pall, Valdek 1969. Põhja-Tartumaa kohanimed I. Tallinn.

Rev 1624/27 = Das Dorpater Land 1624/27. I, 1965. Hrs. Oleg Roslavlev. Hefte zur Landeskunde Estlands.

Ross, Kristiina 2009. Kirjaliku eesti lause poole. Tähelepanekuid paari käändelise verbivormi ja neid sisaldavate tarindite kirjakeelde sugenemisest. - Keel ja Kirjandus 12, 889-907.

Saareste, Andrus 2006. Kaunis emakeel. Vesteid eesti keele elust-olust. Näiteid eesti keelest ja meelest 1524-1958. Tallinn: Eesti Keele Sihtasutus.

Saarikivi, Janne 2006. Substrata Uralica. Studies on Finno-Ugrian substrate in northen Russian dialects. Tartu University Press; http://ethesis.helsinki. fi/julkaisut/hum/suoma/vk/saarikivi/substrat.pdf.

Saks, Aleksander 1984. Kust sai Valga oma nime? - Eesti Loodus 9, 582-584.

Sepper jt 2004 = Maria-Maren Sepper, Argo Mund, Külli Kuusk. Emakeele Seltsis. - Keel ja Kirjandus 7, 555-559.

SPNK $=$ Suomalainen paikannimikirja. 2007. Helsinki: Karttakeskus, Kotimaisten kielten tutkimuskeskus.

SSA = Suomen sanojen alkuperä. Etymologinen sanakirja. 3 (R-Ö), 2000. Päätoim. Ulla-Maija Kulonen. (= Suomalaisen Kirjallisuuden Seuran toimituksia 556, Kotimaisten kielten tutkimuskeskuksen julkaisuja 62.) Helsinki: Suomalaisen Kirjallisuuden Seura, Kotimaisten kielten tutkimuskeskus. 
Tarvel, Enn 1975. Kas Otšela tšuudid olid Koivalinna eestlased? - Keel ja Kirjandus 9, 549-553.

Uustalu, Koidu 1972. Lõuna-Eesti saksakeelne toponüümika (mõisanimed). Väitekiri filoloogiakandidaadi teadusliku kraadi taotlemiseks. Käsikiri Tartu ülikooli raamatukogus. Tartu: Tartu Riiklik Ülikool.

Valgamaa = Eesti. Maateaduslik, tulunduslik ja ajalooline kirjeldus. V, Valgamaa. 1923. Tartu: Eesti Kirjanduse Seltsi kirjastus.

Vasmer, M[ax] 1923. Zur baltischen Ortsnamenforschung. - Sitzungsberichte der gelehrten estnischen Gesellschaft 1922. Dorpat, 75-76.

Viitso, Tiit-Rein, Valts Ernštreits 2012. Līoõkiel-estikīel-leţkīel sõnārōntõz. Liivi-eesti-läti sõnaraamat. Lībiešu-igauņu-latviešu vārdnīca. Tartu Ülikool. 


\title{
Place names motivated by water and waterways on the southern border of Estonia
}

\author{
Mariko Faster
}

The article focuses on some etymologies of place names on the southern border of Estonia, which are related to the water bodies and waterways. The majority of the examples are from southern Estonia, but some are also from other areas of Estonia as well as other Finnic-speaking areas. There are some fossilized appellatives in Estonian place names, which can be explained by other Finnic languages. At first glance the names of these places remain etymologically obscure.

According to researchers, the etymology of the name of the town Valga originates from the Slavic word volok 'portage' or 'the place at which two navigable rivers are closest to each other and where ships and freight can be transported on dry land by the shortest route from one river to the other'. The plausibility of the explanation is supported by its location. The other suggested etymologies seem to be implausible because of lack of convincing naming motivation. Furthermore, the etymology of the equivalent appellative valgma 'portage' is also likely to be volok. There are also some other toponyms named as valgma elsewhere in Estonia. The name of the monastery of Kärkna Falkenau (Ger) is well known. The historical name Walgatabalwe also includes the equivalent element.

The name Taheva (village) originates from the appellative taive, which means 'beginning of the journey' or 'confluence'. Taebla and Taevere belong to the same name cluster, probably with some other place names, for example, the name of Sangaste parish $T(h)$ eal (Ger).

The rivers Mustjogi and Peetri joggi are tributaries of the river Koiva (Latv Gauja). The name Mustjoggi (must 'black', jõgi 'river') is transparent for speakers of contemporary Estonian. The same river has been called with different names in historical sources. The river has also been named in accordance with various riverfront villages, such as Tsooru (Fierenhof), Taheva (Thaywa), and Saru (Scharra). The river name Peetri jõgi, known in Latvian as Melnupe (melns 'black', upe 'river'), dates back to the $18^{\text {th }}$ century and originates from a personal name. An earlier name of the same river was Ihte jõgi; the etymology of this name is obscure.

A look at the geographical location of Saru village suggests that the earlier hypothesis about its origin from the appellative horn is not well substantiated. The name may have been a genuine hydronym (there are a few references from the 1600s), stemming from the appellative $\operatorname{sar}(a)<*_{s a}(a)$ ra 'brook; distributary', which is better known in Eastern Finnic languages. 
The village name Hargla originates from the hydronym (Hargla brook) as well. It also means a brook or a distributary. In Estonian the la-suffix at the end of hydronyms is rather common, unlike Finnish where the suffix -la denotes settlement names.

This article shows that besides knowledge of the old records of place names, it is also essential to be familiar with the geographical location of the place and understand the naming motives. When all this is taken into account, etymologies will be more reliable.

Keywords: onomastics, etymology, hydronyms, settlement names, principles of name giving

Mariko Faster

eesti ja üldkeeleteaduse instituut

Tartu Ülikool

Jakobi 2

51014 Tartu

mariko.faster@ut.ee

Võru Instituut

Tartu 48

65609 Võru

mariko.faster@wi.ee 